\title{
Determination of glomerular function in advanced renal failure
}

\author{
F. MANZ, H. ALATAS, W. KOCHEN, P. LUTZ, W. REBIEN, AND K. SCHÄRER \\ From the Department of Paediatrics, University of Heidelberg, Federal Republic of Germany
}

SUMMARY In 15 children with advanced chronic renal failure, glomerular filtration rate was determined by different methods. Inulin clearance correlated well with the mean of creatinine and urea clearance, and also with 51-chromium edetic acid (EDTA) clearance measured over 24 hours. The absolute values of creatinine clearance and of ${ }^{51} \mathrm{Cr}$-EDTA clearance measured up to 8 hours were higher than inulin clearance. In advanced renal failure both the ${ }^{51} \mathrm{Cr}$-EDTA clearance measured over 24 hours, and the mean of creatinine and urea clearance, provide acceptable estimates of true glomerular filtration rate.

The measurement of residual renal function is important in planning dialysis and transplant programmes, and serial measurements of glomerular filtration rate (GFR) are the most suitable method of predicting when dialysis will be required. Different methods of measuring GFR in advanced chronic renal failure have been compared in adults (Lubowitz et al., 1967; Lavender et al., 1969; Skov, 1970; Favre, 1973; Milutinovic et al., 1975), but there are no comparable studies in children.

\section{Patients and methods}

Fifteen children, mean age 11 years (range 3-16), with advanced chronic renal failure were investigated; their diagnoses are shown in the Table. All children were in a stable condition at the time of the study. 4 were investigated twice. On the first day, GFR was determined by creatinine clearance $\left(\mathrm{C}_{\mathrm{CR}}\right)$ and urea clearance $\left(\mathrm{C}_{\text {Ureas }}\right)$ with a 24-hour urine collection and a single serum specimen. The arithmetical mean of both clearance values (Lubowitz et al., 1967) was also calculated. $\mathrm{C}_{\mathrm{CR}}$ was also estimated from serum creatinine and body height (Counahan et al., 1976).

On the second day a standard inulin clearance $\left(\mathrm{C}_{\mathrm{IN}}\right)$ was performed with three collection periods (Stalder, 1960), each lasting for 20 minutes, and the single injection clearance of 51-chromium edetic acid (EDTA, Amersham) was determined. For the calculation of the EDTA clearances $\left(\mathrm{C}_{\mathrm{EDTA}}\right)$ the radioactivity was measured in 10 serum specimens obtained $5,10,15,30,60,90,120,180,360$, and 1440 minutes after injection of EDTA on the basis

Received 12 January 1977 of the two-compartment model of Sapirstein (Donath, 1971). The resolution of the plasmadisappearance curve was performed graphically in two different ways. Firstly, by using all sera up to 8 hours after injection $\left(C_{\text {EDTA } 8}\right)$, and secondly, by considering the serum specimens from 5 to 60 minutes and at 24 hours only $\left(\mathrm{C}_{\mathrm{EDTA24}}\right)$. The only difference between the two procedures to calculate $\mathrm{C}_{\mathrm{EDTA}}$ was a different half-life time of the latter part of the plasma disappearance curve.

Standard techniques were used for the analytical procedures (Richterich, 1968; Brodehl, 1969; Helger et al., 1974) and for the evaluation of correlation coefficients ( $r$ ). The calculation of the coefficient of variation of the three inulin clearance periods in each of the 15 patients was based on the logarithmic values (Zender et al., 1968).

\section{Results}

The results obtained by the different methods for the evaluation of GFR are compared in the Table. $C_{I N}$ ranged between 0.9 and $18.1 \mathrm{ml} / \mathrm{min}$ per $1.73 \mathrm{~m}^{2}$. The mean coefficient of variation of the three $\mathrm{C}_{\mathrm{IN}}$ collection periods in each patient was $16 \%$. Figs. 1, 2 , and 3 compare the alternative methods of measuring GFR with $\mathrm{C}_{\mathrm{IN}}$. The correlation between $\mathrm{C}_{\mathrm{IN}}$ and the reciprocal values of serum creatinine $\left(S_{C R}\right)$ and serum urea $\left(\mathbf{S}_{\text {Ureas }}\right)$ was poor but improved when $\mathrm{S}_{\mathrm{CR}}$ was corrected for height (Table) (Counahan $e t$ al., 1976). The correlations to $C_{\mathrm{CR}}$ and to $C_{\mathrm{Urea}}$ were good, but mean $C_{C R}$ overestimated $C_{I N}$ by $40 \%$, whereas the mean $\mathrm{C}_{\mathrm{Uren}}$ was $22 \%$ less than $\mathrm{C}_{\mathrm{IN}}$. A high correlation as well as an acceptable agreement 
Table Determination of glomerular function in 15 children with advanced renal failure

\begin{tabular}{|c|c|c|c|c|c|c|c|c|c|}
\hline \multirow[b]{2}{*}{ Diagnosis } & \multirow[b]{2}{*}{$\begin{array}{l}\text { Height } \\
(\mathrm{cm})\end{array}$} & \multirow[b]{2}{*}{$\begin{array}{l}C_{I N} \\
\left(\mathrm{ml} / \mathrm{min} \text { per } 1.73 \mathrm{~m}^{2}\right)\end{array}$} & \multirow[b]{2}{*}{$\begin{array}{l}S c R \\
(\mathrm{mg} / 100 \mathrm{ml})\end{array}$} & \multirow[b]{2}{*}{$\frac{0.43 \times \text { height }}{S C R}$} & \multicolumn{5}{|c|}{ Clearances ( $\mathrm{ml} / \mathrm{min}$ per $\left.1 \cdot 73 \mathrm{~m}^{2}\right)$} \\
\hline & & & & & $C C R$ & Corea & \multicolumn{2}{|c|}{$\frac{C C R+C U_{r e a}}{2}$} & $C_{E D T A 24}$ \\
\hline $\begin{array}{l}\text { Oligomeganephronic } \\
\text { hypoplasia } \\
\text { Renal dysplasia } \\
\text { Nephronophthisis } \\
\text { ", } \\
\qquad, " \\
\text { ", } \\
\text { Chronic pyelonephritis } \\
\text { Endo-+ extracapillary } \\
\text { glomerulonephritis } \\
\text { Henoch-Schönlein nephritis } \\
\text { Mean } \\
\text { Coefficient of correlation (r) }\end{array}$ & $\begin{array}{l}90 \\
99 \\
140 \\
124 \\
130 \\
159 \\
130 \\
121 \\
126 \\
148 \\
148 \text { ) } \\
150 \\
144 \\
142 \\
140 \\
170 \\
149 \\
155 \\
106 \\
\\
\text { (o CIN }\end{array}$ & $\begin{array}{r}5 \cdot 4 \\
5 \cdot 7 \\
4 \cdot 2 \\
5 \cdot 3 \\
12 \cdot 0 \\
8 \cdot 3 \\
11 \cdot 8 \\
11 \cdot 7 \\
9 \cdot 4 \\
7 \cdot 7 \\
7 \cdot 0 \\
5 \cdot 4 \\
7 \cdot 5 \\
8 \cdot 4 \\
0 \cdot 9 \\
18 \cdot 1 \\
17 \cdot 9 \\
6 \cdot 9 \\
8 \cdot 5 \\
8 \cdot 5\end{array}$ & $\begin{array}{r}3 \cdot 3 \\
4 \cdot 8 \\
14 \cdot 8 \\
6 \cdot 5 \\
4 \cdot 9 \\
6 \cdot 3 \\
4 \cdot 0 \\
3 \cdot 1 \\
7 \cdot 2 \\
5 \cdot 6 \\
6 \cdot 7 \\
8 \cdot 1 \\
5 \cdot 0 \\
6 \cdot 3 \\
13 \cdot 9 \\
3 \cdot 4 \\
1 \cdot 7 \\
3 \cdot 8 \\
2 \cdot 5 \\
1 / 0 \cdot 69\end{array}$ & $\begin{array}{r}12 \cdot 2 \\
9 \cdot 3 \\
4 \cdot 2 \\
8 \cdot 6 \\
11 \cdot 9 \\
10 \cdot 8 \\
14 \cdot 6 \\
17 \cdot 6 \\
7 \cdot 9 \\
11 \cdot 9 \\
9 \cdot 9 \\
8 \cdot 3 \\
12 \cdot 9 \\
10 \cdot 1 \\
4 \cdot 5 \\
22 \cdot 5 \\
38 \cdot 8 \\
18 \cdot 3 \\
19 \cdot 1 \\
13 \cdot 3 \\
0 \cdot 80\end{array}$ & $\begin{array}{r}7 \cdot 6 \\
9 \cdot 6 \\
3 \cdot 9 \\
7 \cdot 3 \\
14 \cdot 8 \\
12 \cdot 2 \\
20 \cdot 2 \\
17 \cdot 3 \\
8 \cdot 6 \\
10 \cdot 2 \\
14 \cdot 3 \\
6 \cdot 7 \\
9 \cdot 2 \\
10 \cdot 2 \\
2 \cdot 6 \\
17 \cdot 6 \\
25 \cdot 0 \\
18 \cdot 5 \\
11 \cdot 2 \\
11 \cdot 9 \\
0 \cdot 83\end{array}$ & $\begin{array}{r}4 \cdot 6 \\
3 \cdot 5 \\
3 \cdot 0 \\
5 \cdot 4 \\
9 \cdot 8 \\
5 \cdot 9 \\
9 \cdot 4 \\
10 \cdot 5 \\
6 \cdot 4 \\
7 \cdot 0 \\
6 \cdot 9 \\
3 \cdot 5 \\
4 \cdot 4 \\
6 \cdot 0 \\
1 \cdot 3 \\
16 \cdot 3 \\
8 \cdot 0 \\
9 \cdot 1 \\
5 \cdot 4 \\
6 \cdot 6 \\
0 \cdot 83\end{array}$ & $\begin{array}{c}6 \cdot 1 \\
6 \cdot 5 \\
3 \cdot 5 \\
6 \cdot 4 \\
12 \cdot 3 \\
9 \cdot 0 \\
14 \cdot 8 \\
13 \cdot 9 \\
7 \cdot 5 \\
8 \cdot 6 \\
10 \cdot 6 \\
5 \cdot 1 \\
6 \cdot 8 \\
8 \cdot 1 \\
1 \cdot 9 \\
17 \cdot 0 \\
16 \cdot 6 \\
13 \cdot 8 \\
8 \cdot 3 \\
9 \cdot 3 \\
0 \cdot 89\end{array}$ & $\begin{array}{c}9 \cdot 1 \\
6 \cdot 5 \\
5 \cdot 5 \\
7 \cdot 6 \\
10 \cdot 9 \\
13 \cdot 7 \\
16 \cdot 2 \\
15 \cdot 6 \\
7 \cdot 5 \\
9 \cdot 6 \\
8 \cdot 5 \\
10 \cdot 3 \\
6 \cdot 1 \\
10 \cdot 6 \\
16 \cdot 6 \\
12 \cdot 9 \\
26 \cdot 3 \\
10 \cdot 9 \\
16 \cdot 4 \dagger \\
11 \cdot 4 \\
0 \cdot 56\end{array}$ & $\begin{array}{c}- \\
5 \cdot 6 \\
3 \cdot 6 \\
5 \cdot 5 \\
10 \cdot 0 \\
7 \cdot 8 \\
10 \cdot 4 \\
9 \cdot 2 \\
7 \cdot 1 \\
6 \cdot 6 \\
6 \cdot 8 \\
6 \cdot 7 \\
5 \cdot 8 \\
8 \cdot 7 \\
4 \cdot 2 \\
15 \cdot 7 \\
9 \cdot 2 \\
16 \cdot 7 \dagger \\
7 \cdot 7 \\
0 \cdot 92\end{array}$ \\
\hline
\end{tabular}

* Parenthesis indicates same patient investigated twice.

tThis is the only patient with important proteinuria and overt oedema. These values are not included in calculation of the mean and $r$. Conversion: Traditional units to $S I-$ Serum creatinine: $1 \mathrm{mg} / 100 \mathrm{ml} \approx 88 \cdot 4 \mu \mathrm{mol} / \mathrm{l}$.

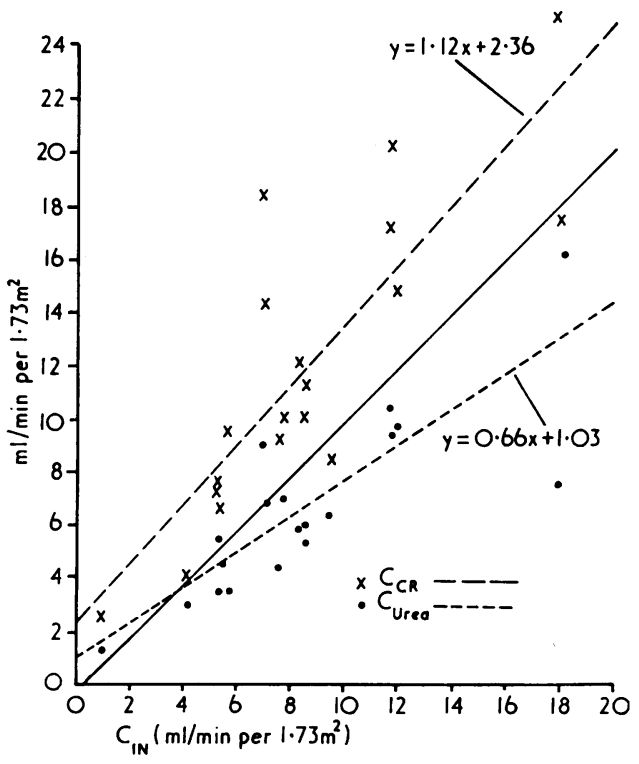

Fig. 1 Inulin clearance $\left(C_{I N}\right)$ related to creatinine clearance and urea clearance.

with the mean value of $\mathrm{C}_{\mathrm{IN}}(+9 \%)$, were obtained with $\left(\mathrm{C}_{\mathrm{CR}}+\mathrm{C}_{\mathrm{Ures}}\right) / 2$ (Fig. 2).

$\mathrm{C}_{\text {EDTA8 }}$ did not significantly correlate with $\mathrm{C}_{\mathrm{IN}}$ $(\mathrm{P}<0.01)$, and overestimated it by $36 \%$. On the other hand, $\mathrm{C}_{\mathrm{EDTA24}}$ correlated well with $\mathrm{C}_{\mathrm{IN}}(\mathrm{r}=0.92)$ and underestimated it by only $6 \%$.

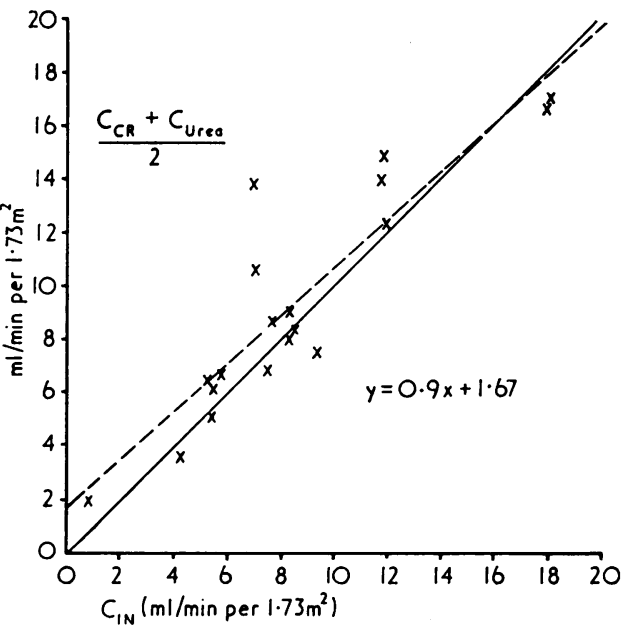

Fig. 2 Inulin clearance related to the mean of creatinine and urea clearance.

\section{Discussion}

It is generally accepted that while $C_{I N}$ is the most accurate method of measuring GFR, even in advanced uraemia (Hierholzer et al., 1972), it is not applicable to routine clinical practice (Barratt and Chantler, 1975). In adults the variation coefficient of $\mathrm{C}_{\mathrm{IN}}$ in the same patient with normal or slightly impaired GFR varies between 8 and $12 \%$ (Zender et al., 1968; Kramer et al., 1974). In the present 


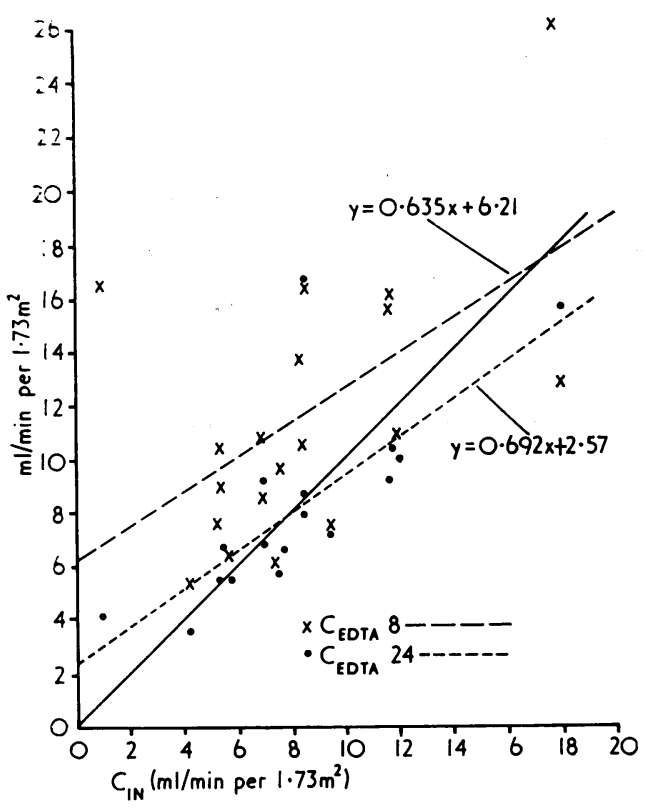

Fig. 3 Inulin clearance related to 51-chromium edetic acid clearance $\left(C_{E D T A}\right)$ measured up to 8 and 24 hours.

series of children with advanced chronic renal failure the variation coefficient was slightly higher.

$\mathrm{C}_{\mathrm{CR}}$ overestimates GFR especially in chronic renal failure. This has been attributed to tubular secretion of creatinine, to fluctuations in the daily creatinine formation and excretion, and to interference of creatinine chromogenic material with the Jaffé reaction (Lubowitz et al., 1967; Kim et al., 1969; Hierholzer et al., 1972). It has been known for a long time, that $\mathbf{C}_{\text {Urea }}$ underestimates GFR and is highly dependent on dietary protein intake. On the other hand, Lubowitz et al. (1967) showed in adults with advanced chronic renal failure that the mean of $\mathrm{C}_{\mathrm{CR}}$ and $C_{\text {Urea }}$ gives a good estimate of the true GFR. Our results show that the same applies to children with advanced chronic renal failure.

Recently isotopic single injection clearance techniques have become increasingly popular for the estimation of true GFR because of their simplicity, accuracy, and noninvasive nature. $\mathrm{C}_{\mathrm{EDTA}}$ has been tested in large groups of children with normal or slightly impaired renal function (Vögeli et al., 1971; Chantler and Barratt, 1972). Few data, however, have been published on the determination of GFR by $C_{E D T A}$ in children with advanced chronic renal failure (Vögeli et al., 1971). In adults with advanced chronic renal failure the single injection technique $\left(C_{\text {EDTA }}\right)$ overestimates GFR (Favre, 1973). This has been attributed to an expansion of the extracellular volume, present even in the absence of overt oedema.
In newborn infants a similar mechanism seems to be responsible for the overestimation of GFR after feeding (Broberger, 1973).

The mathematical model used to analyse the falling plasma concentration curve is in any case an approximation and involves an overestimate of the plasma clearance of the chelate (Chantler et al., 1969). This overestimate is small but becomes relatively more important when GFR is low and can be corrected for by extending plasma sampling (Maisey et al., 1969).

Our study with $\mathrm{C}_{\text {EDTi24 }}$ suggests that in patients with advanced chronic renal failure one blood sample should be taken at 24 hours after injection to obtain an acceptable correlation with true GFR.

References

Barratt, T. M., and Chantler, C. (1975). Clinical assessment of renal function. Pediatric Nephrology, p. 55. Ed. by M. I. Rubin and T. M. Barratt. Williams and Wilkins, Baltimore.

Broberger, U. (1973). Determination of glomerular filtration rate in the newborn. Acta Paediatrica Scandinavica, 62, 625-629.

Brodehl, J. (1969). Der renale Transport der Aminosäuren im Säuglings- und Kindesalter. Archiv für Kinderheilkunde, Suppl. 61.

Chantler, C., and Barratt, T. M. (1972). Estimation of glomerular filtration rate from plasma clearance of 51chromium edetic acid. Archives of Disease in Childhood, 47, 613-617.

Chantler, C., Garnett, E. S., Parsons, V., and Veall, N. (1969). Glomerular filtration rate measurement in man by the single injection method using ${ }^{51} \mathrm{Cr}$ EDTA. Clinical Science, 37, 169-180.

Counahan, R., Chantler, C., Ghazali, S., Kirkwood, B., Rose, F., and Barratt, T. M. (1976). Estimation of glomerular filtration rate from plasma creatinine concentration in children. Archives of Disease in Childhood, 51, 875-878.

Donath, A. (1971). The simultaneous determination in children of glomerular filtration rate and effective renal plasma flow by the single injection clearance technique. Acta Paediatrica Scandinavica, 60, 512-520.

Favre, H. (1973). Détermination des fonctions rénales par la technique de l'injection unique. Journal d'Urologie et de Néphrologie, 79, 1007-1052.

Helger, R., Rindfrey, H., and Hilgenfeldt, J. (1974). Eine Methode zur direkten Bestimmung des Creatinins im Serum und Harn ohne Entweißung nach einer modifizierten Jaffé-Methode. Zeitschrift für klinische Chemie und klinische Biochemie, 12, 344-349.

Hierholzer, K., Butz, M., and Baethke, R. (1972). Evaluation of measurement of reduced glomerular filtration rate in the severely diseased kidney. Uremia, p. 98 . Ed. by R. Kluthe, G. Berlyne, and B. Burton. Thieme, Stuttgart.

Kim, K. E., Onesti, G., Ramirez, O., Brest, A. N., and Swartz, C. (1969). Creatinine clearance in renal disease. British Medical Journal, 4, 11-14.

Kramer, P., Köthe, E., and Girndt, J. (1974). Konventionelle Clearanceverfahren. Stand und Bedeutung. Mitteilungen der Arbeitsgemeinschaft für klinische Nephrologie, 3, 25-56.

Lavender, S., Hilton, P. J., and Jones, N. F. (1969). The measurement of glomerular filtration-rate in renal disease. Lancet, 2, 1216-1218. 
Lubowitz, H., Slatopolsky, E., Shankel, S., Rieselbach, R. E., and Bricker, N. S. (1967). Glomerular filtration rate. Journal of the American Medical Association, 199, 252-256.

Maisey, M. N., Ogg, C. S., and Cameron, J. S. (1969). Measuring glomerular filtration-rate. Lancet, 1, 733.

Milutinovic, J., Cutler, R. E., Hoover, P., Meijsen, B., and Scribner, B. H. (1975). Measurement of residual glomerular filtration rate in the patient receiving repetitive hemodialysis. Kidney International, 8, 185-190.

Richterich. R. (1968). Harnstoff-N: Urease Spaltung und Bestimmung nach Berthelot. Klinische Chemie, 2nd ed., p. 254. Akademische Verlagsgesellschaft, Frankfurt.

Skov, P. E. (1970). Glomerular filtration rate in patients with severe and very severe renal insufficiency. Acta Medica Scandinavica, 187, 419-428.

Stalder, G. (1960). Clearance-Untersuchungen im Kinde- salter. Moderne Probleme der Paediatrie, Vol. 6, pp. 195229. Karger, Basel.

Vögeli, B., Riedwyl, H., Donath, A., and Oetliker, O. (1971). Comparison of glomerular filtration rate and effective renal plasma flow determinations obtained by a single injection technique and by means of a standard clearance technique in children. Acta Paediatrica Scandinavica, 60, 528-532.

Zender, R., Vuagnat, P., and Falbriard, A. (1968). Étude statistique des causes d'erreur dans la mesure d'une clearance rénale conventionelle. Clinica Chimica Acta, 20, 85-88.

Correspondence to Dr. F. Manz, Universitätskinderklinik Im Neuenheimer Feld 150, D-6900 Heidelberg, Federal Republic of Germany.

The following articles will appear in future issues of this journal:

Role of infection in death of children with acute lymphoblastic leukaemia. A. W. Craft, M. M. Reid, E. Bruce, J. Kernahan, and P. S. Gardner.

Lactose intolerance, detected by the hydrogen breath test, in infants and children with chronic diarrhoea. H. V. L. Maffei, G. Metz, V. Bampoe, M. Shiner, S. Herman, and C. G. D. Brook.

Relation of maternal and cord blood serum ferritin. M. A. M. Hussain, T. H. Gaafar, Martine Laulicht, and A. V. Hoffbrand.

Aural temperature of the newborn infant. D. Stratton.

Diabetes insipidus, diabetes mellitus, optic atrophy, and deafness: 3 cases of 'DIDMOAD' syndrome. Joyce E. Richardson and W. Hamilton.

Pseudohypoparathyroidism. Variable manifestations within a family. A. J. Williams, J. L. Wilkinson, and W. H. Taylor. 